
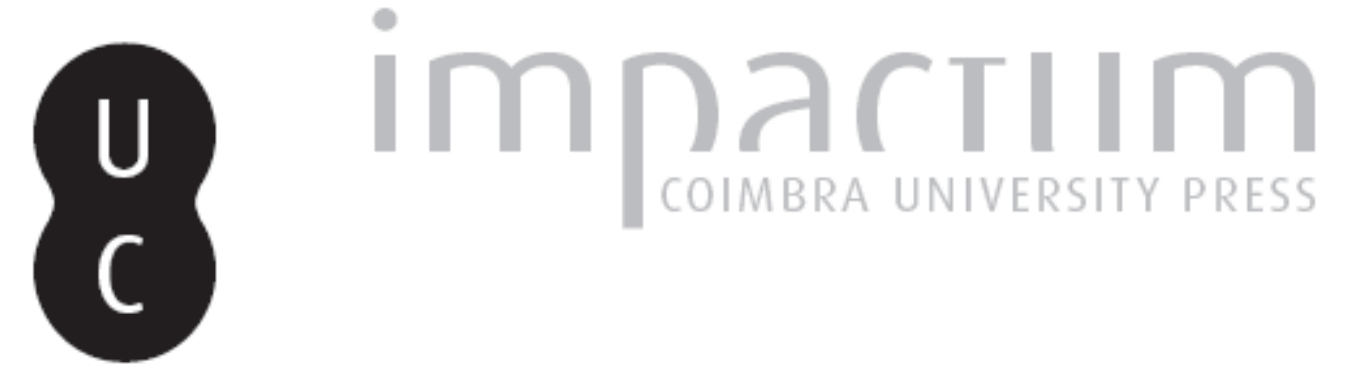

A organização interna do Partido Republicano Nacionalista (19231935)

Autor(es): Baiôa, Manuel

Publicado por: Imprensa da Universidade de Coimbra

URL persistente:

URI:http://hdl.handle.net/10316.2/40966

DOI:

DOI:https://doi.org/10.14195/1645-2259_16_16

Accessed : $\quad$ 26-Apr-2023 13:03:33

A navegação consulta e descarregamento dos títulos inseridos nas Bibliotecas Digitais UC Digitalis, UC Pombalina e UC Impactum, pressupõem a aceitação plena e sem reservas dos Termos e Condições de Uso destas Bibliotecas Digitais, disponíveis em https://digitalis.uc.pt/pt-pt/termos.

Conforme exposto nos referidos Termos e Condições de Uso, o descarregamento de títulos de acesso restrito requer uma licença válida de autorização devendo o utilizador aceder ao(s) documento(s) a partir de um endereço de IP da instituição detentora da supramencionada licença.

Ao utilizador é apenas permitido o descarregamento para uso pessoal, pelo que o emprego do(s) título(s) descarregado(s) para outro fim, designadamente comercial, carece de autorização do respetivo autor ou editor da obra.

Na medida em que todas as obras da UC Digitalis se encontram protegidas pelo Código do Direito de Autor e Direitos Conexos e demais legislação aplicável, toda a cópia, parcial ou total, deste documento, nos casos em que é legalmente admitida, deverá conter ou fazer-se acompanhar por este aviso.






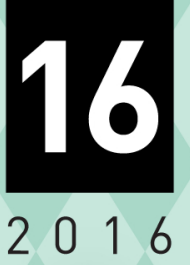

\section{Revista \\ de História \\ da Sociedade \\ e da \\ Cultura}




\title{
A organização interna do Partido Republicano Nacionalista $(1923-1935)^{1}$
}

\section{The internal organization of the Republican Nationalist Party (1923-1935)}

\author{
MANuel BaiôA \\ Universidade de Évora - CIDEHUS \\ manuelbaioa@hotmail.com
}

Texto recebido em / Text submitted on: 04.04.2016

Texto aprovado em / Text approved on: 15.06.2016

Resumo: O Partido Republicano Nacionalista (PRN) tinha um estatuto e uma estrutura organizativa semelhante aos restantes partidos republicanos portugueses. O Diretório era o órgão diretivo supremo e era coadjuvado pela Comissão Administrativa, órgão encarregue da burocracia. A nível central havia ainda a Junta Consultiva e o Grupo Parlamentar. A nível regional, o PRN estava organizado em função da estrutura administrativa do país. A sua rede partidária era abrangente, mas ficava aquém do principal partido do regime - Partido Republicano Português, vulgarmente conhecido como Partido Democrático. O PRN tinha um aparato organizativo simples, típico dos partidos de quadros, ainda sem um rol de funcionários que caracterizava os partidos de massas em ascensão na Europa. A organização assentava num conjunto alargado de notáveis e caciques, unidos entre si por laços de parentesco e clientelas. Em suma, embora começassem a surgir alguns elementos de modernização, o PRN continuava com uma organização deficiente, irregular, intermitente e pouco estruturada.

Palavras-chave: Partido Republicano Nacionalista; partidos; elites; Primeira República Portuguesa; estrutura partidária.

Abstract: The Republican Nationalist Party (RNP) had a statute and an organizational structure similar to other Portuguese republican parties. The Directory was the supreme governing organism, assisted by the Administrative Commission, the body in charge of the bureaucracy. At the central level there was the Advisory Board and the Parliamentary Group. Regionally the RNP was organized according to the country's administrative structure. The party network was comprehensive, but distant from the main party of the regime - the Portuguese Republican Party, known as Democratic Party. The RNP had a simple organizational apparatus, typical of cadre parties, still without the list of employees that characterized the mass parties rising in Europe. The organization was based on a large number of notables and local political leaders, linked by kinship ties and clienteles. In short, although

1 Trabalho desenvolvido no âmbito de UID/HIS/00057/2013 (POCI-01-0145-FEDER-007702), FCT/Portugal, COMPETE, FEDER, Portugal2020. 
some elements of modernization began to emerge, the RNP went on having a deficient, irregular, intermittent and poorly structured organization.

Keywords: Republican Nationalist Party; parties; elites; First Portuguese Republic; party structure.

\section{Introdução}

O Partido Republicano Nacionalista (PRN) formou-se em fevereiro de 1923, fruto da fusão do Partido Republicano Liberal (PRL) com o Partido Republicano de Reconstituição Nacional (PRRN). Durante a fase final da I República foi a segunda força política do regime, representando o republicanismo conservador que se opunha ao Partido Republicano Português (PRP), comummente conhecido como Partido Democrático, que era o partido dominante do regime e que representava o republicanismo histórico e radical. O PRN apenas liderou um governo ( 15 novembro a 18 de dezembro de 1923) e teve duas cisões que o enfraqueceram. A primeira foi liderada por Álvaro de Castro em dezembro de 1923, tendo-se formado o Grupo Parlamentar de Ação Republicana. A segunda foi liderada por Cunha Leal em março de 1926, surgindo então a União Liberal Republicana. Contudo, durante este período incorporaram-se dois partidos ao PRN: o Partido Reformista/Federação Nacional Republicana ingressou no PRN em maio de 1923 e o Partido Nacional Republicano Presidencialista incorporou-se no PRN em março de 1925. Após o início da Ditadura Militar o PRN oscilou entre o estabelecimento de um compromisso com os líderes da Ditadura ou fazer parte do movimento que queria derrubar o novo regime por via revolucionária - "o reviralho". O PRN acabaria por dissolver-se a 7 de fevereiro de 1935, após alguns dos seus mais importantes dirigentes terem aderido ao Estado Novo. No entanto, outros membros da elite do PRN continuaram a militar na oposição durante longas décadas (Baiôa 2015: 62-464).

Neste estudo pretendemos analisar a organização interna do PRN, examinando o seu estatuto e os seus órgãos diretivos centrais e locais, ao mesmo tempo que estabelecemos comparações com outros partidos portugueses e estrangeiros, identificando semelhanças e diferenças numa dimensão essencialmente sincrónica. Dada a limitação de espaço, os tópicos ligados aos centros políticos, imprensa e financiamento não vão ser tratados neste texto ${ }^{2}$. Uma vez que se desconhece o paradeiro dos arquivos centrais e regionais do PRN teve de recorrer-se a outras fontes, principalmente à imprensa e a arquivos privados.

2 Sobre estes assuntos veja-se Baiôa (no prelo): 127-145. 


\section{O Estatuto ou Lei Orgânica}

Após a constituição do PRN foi nomeada uma comissão encarregue da elaboração da lei orgânica do partido. Esta comissão era constituída por um antigo membro do PRRN, Rodolfo Xavier da Silva, e por um antigo membro do PRL, Paulo da Costa Menano (República 20/02/1923: 2; O Século 22/02/1923: 2). Esta comissão entregou uma primeira versão do "Estatuto ou Lei Orgânica" do partido para ser apreciada pelo Diretório e por uma comissão parlamentar do PRN. Estes organismos efetuaram algumas alterações à proposta inicial ${ }^{3}$. Uma última versão foi apresentada durante o I Congresso do PRN, que decorreu no ginásio do Liceu Camões, em Lisboa, nos dias 17, 18 e 19 de março de 1923. Esta proposta sofreu algumas críticas por parte de alguns congressistas que discordavam do poder do Diretório na nomeação dos candidatos a deputados. No entanto, estas apreciações não foram atendidas, sendo o "Estatuto ou Lei Orgânica" (Estatuto 1923) aprovado quase sem alterações e com pouca discussão (República 18/03/1923: 2 e 20/03/1923: 2; O Século 20/03/1923: 1). O "Estatuto ou Lei Orgânica” do PRN estava mais próximo do Estatuto do Partido Republicano Liberal (Estatuto 1919) do que da Lei Orgânica do Partido Republicano de Reconstituição Nacional ${ }^{4}$.

Segundo o estatuto, o PRN era um agrupamento político que reunia "todos os republicanos portugueses que aceitam, cumprem e defendem o programa e a sua lei orgânica" e tinha por objetivo "contribuir para o benefício da Pátria e prestígio da República". Para além das estruturas nacionais, distritais, concelhias e de freguesias do PRN, faziam parte deste partido "os centros políticos e outras coletividades de propaganda e instrução e beneficência filiadas no partido, bem como jornais reconhecidos pelo Diretório" (Estatuto 1923: 3-4, $\operatorname{art}^{\circ} 1^{\circ}, 2^{\circ}$ e $4^{\circ}$ ).

A filiação e inscrição no PRN era altamente descentralizada, podendo ser feita "perante qualquer das comissões, desde as paroquiais até ao Diretório ou perante os centros devidamente reconhecidos, ouvidas as comissões paroquiais" (Estatuto 1923: 4, $\operatorname{art}^{\circ} 6^{\circ}$ ). As comissões hierarquicamente mais baixas apenas tinham de comunicar todas as filiações que recebiam às comissões hierarquicamente mais altas, até chegar ao Diretório. Portanto, o Diretório recebia a informação da filiação, mas não controlava este processo. Outro aspeto

O "Estatuto ou Lei Orgânica" do partido foi aprovado na reunião do Diretório do dia 1/03/1923; cf.

O Século 2/03/1923: 2 .

4 O Regionalista 22/10/1921:3;29/10/1921: 2-3; 26/11/1921: 3; 11/12/1921: 2. 
relevante era não haver propriamente uma lista unificada dos membros do PRN, mas um somatório dos nacionalistas inscritos nas diferentes comissões de freguesias, concelhias, distritais e centros partidários, podendo um indivíduo estar inscrito ao mesmo tempo em diferentes estruturas. Portanto, o PRN era mais um conglomerado de membros e de notáveis associados em diversas estruturas, do que um corpo organizado com uma estrutura hierárquica bem definida, como acontecia com os partidos de massas daquela época.

\section{Os órgãos diretivos centrais}

O Diretório, composto por sete membros efetivos, era o órgão executivo supremo do PRN. Era eleito anualmente pelo Congresso ${ }^{5}$, órgão onde residia a soberania partidária. $\mathrm{O}$ Diretório era ainda composto por sete membros substitutos ${ }^{6}$, "os quais entrarão em exercício quando faltem os efetivos, por ordem numérica de votos” (Estatuto 1923: 6, arto $25^{\circ}$ ). A opção por um órgão colegial ia ao encontro do republicanismo clássico que considerava esta via mais democrática $^{7}$ e foi a seguida pela maioria dos partidos republicanos portugueses ${ }^{8}$. No entanto, dentro do Diretório era eleito um presidente e um secretário.

António Ginestal Machado assumiu a presidência do Diretório do PRN desde a fundação até 23 de março de 1927, substituído então por Júlio Dantas, que se manteve no cargo até à dissolução do PRN em 7 de fevereiro de 1935. António Ginestal Machado abandonou a presidência do Diretório do PRN naquela altura "por importantes motivos da sua vida particular" (Correio da

5 O Diretório do PRP era eleito bienalmente; cf. Lei Orgânica 1921: 9, cap. VII, artº $26^{\circ}$.

6 No PRP e no PRL o Diretório era composto por nove efetivos e nove suplentes. O Diretório do Partido Republicano da Esquerda Democrática (PRED) era constituído por onze efetivos e onze suplentes; cf. Estatuto 1919: 7, cap. IV, arto 18º; Queirós 2008: 204 e 285.

7 Entrevista a Tomé Barros Queiroz, Diário de Lisboa 1/02/1923: 8: “- O novo partido não terá um chefe... - Não! Será uma junta diretiva, com uma junta parlamentar... organização democrática...."

8 No PRL o Diretório escolhia um presidente e um secretário. No PRP o presidente do Diretório tinha como principal função presidir às reuniões e era designado em cada uma das sessões. Na primeira sessão o presidente escolhia o secretário e o tesoureiro. O Diretório do PRRN era constituído por sete membros efetivos e sete membros substitutos. Estes membros elegiam um presidente e um secretário-geral. O Diretório do PRED escolhia uma Comissão Executiva composta por três membros: presidente, secretário e tesoureiro. Na União Liberal Republicana (ULR) o órgão supremo designava-se Comissão Executiva. Era composta por um presidente, cinco vogais efetivos e cinco vogais substitutos. O presidente era eleito isoladamente em Congresso, por escrutínio secreto, o que fortalecia a sua soberania. Esta organização era semelhante à do Partido Republicano Conservador em 1919. Cf. Estatuto 1919: 7, cap. IV, arto 19; Lei Orgânica 1921: 9, cap. VII, arto 26º O Jornal 4/08/1919: 3; Estatutos 1995: 199-207; O Regionalista, 22/10/1921: 3; 29/10/1921: 2-3; 26/11/1921: 3; 11/12/1921: 2; A Noite 21/04/1926: 3; Queirós 2008: 204 e 285; Silva 1996: 66-68. 
Extremadura 26/03/1927: 2), possivelmente relacionados com a doença do seu filho que viria a falecer no mês seguinte (Correio da Extremadura 9/04/1927: 2). Pedro Pita foi o secretário durante todo este período. O PRN teve ao longo da sua vida 12 membros efetivos e 13 membros substitutos do Diretório, num total de 24 membros. Apenas Belchior de Figueiredo passou da condição de substituto para a condição de efetivo, concluindo-se que os membros substitutos eram líderes partidários de segunda linha. Quando houve renovação dos membros efetivos do Diretório procuraram-se outros líderes, conforme se pode verificar no Quadro 1.

Quadro 1. Diretório do PRN (1923-1935)

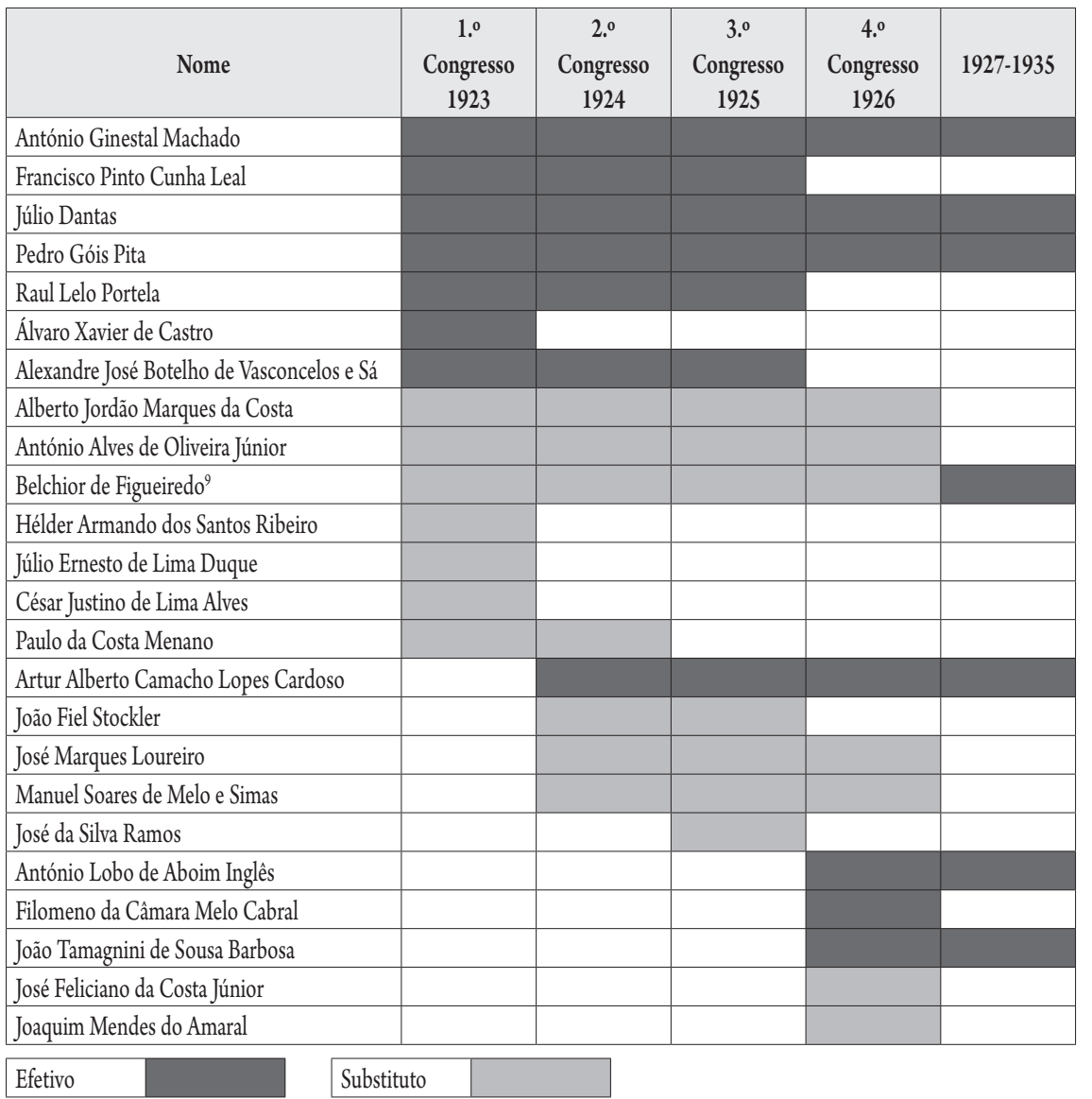

9 Filomeno da Câmara Melo Cabral abandonou o PRN em 19 de junho de 1926, sendo então substituído por Belchior de Figueiredo. Belchior de Figueiredo manteve-se no Diretório até novembro de 1930, data em que se desligou do PRN. 
O Diretório tinha uma vasta área de competências, que passavam pela direção da propaganda do partido e pela organização e desenvolvimento de comissões, centros e outros núcleos do PRN em todo o país. Ao Diretório cabia a responsabilidade de resolver os conflitos internos entre as diversas estruturas do partido. Um dos principais motivos de conflitos entre as estruturas locais e o Diretório do PRN prendia-se com a designação dos candidatos a deputados pelo PRN. O Estatuto ou Lei Orgânica do PRN atribuía ao Diretório o poder de "indicar às comissões políticas os nomes dos candidatos a parlamentares, que julgue conveniente fazer eleger pelo partido" (Estatuto 1923: 8, $\operatorname{art}^{\circ} 27^{\circ}$, alínea 5). Contudo, as comissões políticas locais tinham o poder de "sancionar a escolha de deputados e de senadores" (Estatuto 1923: 13, $\operatorname{art}^{\circ} 41^{\circ}$, alínea 9) efetuada pelo Diretório. Em caso de diferendo, cabia a última palavra ao Diretório, pois embora as comissões políticas locais pudessem apresentar candidaturas ao Senado e à Câmara dos Deputados, o Diretório podia rejeitá-las, fundamentando a sua decisão num parecer (Estatuto 1923: 8, $\operatorname{art}^{\circ} 27^{\circ}$, alínea 6). Esta tensão tinha sido atenuada pela tradição que atribuía às comissões políticas locais o direito a escolher um dos candidatos a deputados por cada círculo eleitoral. No entanto, nem sempre a tradição foi suficiente para atenuar os conflitos entre o centro e a periferia.

O Diretório podia ainda "irradiar do partido por sua iniciativa, mediante processo, os membros que lhe sejam nocivos, resolver sobre os processos de irradiação que lhes sejam apresentados pelas comissões municipais" (Estatuto 1923: 9, $\operatorname{art}^{\circ} 27^{\circ}$, alínea 10).

O Diretório reunia ordinariamente uma vez por semana ${ }^{10}$, embora pudesse reunir extraordinariamente, sempre que a situação política o exigisse. Durante a Ditadura Militar as reuniões começaram a ser mais espaçadas e algumas vezes não houve reunião por falta quórum ${ }^{11}$. $\mathrm{O}$ dia da semana em que se reunia o Diretório foi variando ao longo do tempo. Em

10 República 24/05/1923: 2; Distrito da Guarda 26/10/1924: 1. O Diretório do PRP reunia quinzenalmente. O Diretório do PRRN reunia apenas uma vez por mês, embora a Comissão Executiva do Diretório reunisse semanalmente. Cf. Lei Orgânica 1921: 9, cap. VII, arto ${ }^{\circ} 6^{\circ}$; Silva 1996: 66-68.

11 Júlio Dantas escreveu a António Ginestal Machado em 18 de maio de 1927 dando-lhe conta que a reunião do Diretório não se realizou, pois apenas estiveram presentes, ele próprio, Pedro Pita e Aboim Inglês. A manutenção desta situação estava a provocar algumas discussões e a acentuar a desintegração do PRN, pelo que Júlio Dantas se mostrava muito aborrecido. Noutra carta datada em Lisboa, em 9 de fevereiro de 1928, Júlio Dantas informou o seu correligionário do seguinte: "Há três semanas que não temos número para reunir o Diretório". A justificação prendia-se com o facto de alguns estarem doentes e Belchior de Figueiredo não poder vir às reuniões a Lisboa, por viver no Porto. Em 1930 o problema mantinha-se, mas agravou-se no final do ano, após Belchior de Figueiredo ter-se desligado do PRN em novembro de 1930. A partir desta data as reuniões do Diretório passaram a ser muito irregulares. Cf. cartas de Júlio Dantas para António Ginestal Machado, Espólio 
março de 1926 era às terças-feiras (O Figueirense 11/03/1926: 2), mas em agosto de 1930 era às sextas-feiras (O Debate 17/08/1930: 1). Sempre que um membro efetivo não podia comparecer às reuniões podia ser revezado temporariamente pelos membros substitutos ${ }^{12}$, ou definitivamente, no caso do membro efetivo abandonar o cargo, como sucedeu com Filomeno da Câmara Melo Cabral em 19 de junho de 1926, sendo então substituído por Belchior de Figueiredo.

O Diretório reunia frequentemente no Centro Nacionalista do Calhariz, também conhecido por edifício d' A Lucta, onde funcionava a sede do Diretório. No entanto, também reuniu algumas vezes no edifício do Congresso. Após o início da Ditadura Militar passou a reunir frequentemente na casa de alguns dos seus membros, em particular na casa do presidente Júlio Dantas (Democracia do Sul 15/03/1928: 1).

O Diretório reunia, por vezes, em conjunto com o Grupo Parlamentar para tratar de questões importantes da política nacional. Nos dias 16 e 17 de fevereiro de 1925, as duas estruturas reuniram para analisarem a atitude a tomar após a formação do governo de Vitorino Guimarães, tendo sido analisadas duas possibilidades: obstrucionismo ou abandono do Parlamento (Diário de Lisboa 16/02/1925: 5; 17/02/1925: 5). Nas reuniões semanais ordinárias era feita a gestão quotidiana do PRN, sendo tratados assuntos muito variados. Por vezes, no final destas reuniões era divulgada uma nota oficiosa à imprensa ${ }^{13}$. Não temos muitas informações sobre o processo de deliberações. Por vezes, surgem informações que indiciam votações, como na eleição de António Ginestal Machado e Júlio Dantas para presidente do Diretório (Diário de Lisboa 24/03/1927: 8). No entanto, não sabemos como eram dirimidas internamente as divergências e como se processava o processo de decisão, uma vez que não foi possível localizar as atas destas reuniões e as informações recolhidas nos arquivos pessoais e na imprensa são escassas.

António Ginestal Machado, Biblioteca Nacional de Portugal (EAGM/BNP), Espólio E55/784, 790, $809,810$.

12 Como Júlio Dantas foi ao Brasil em viagem, Alberto Jordão Marques da Costa substituiu-o no Diretório por ser o substituto mais votado; cf. Democracia do Sul 12/06/1923: 2.

13 Na reunião realizada no dia 16 de junho de 1925 saiu a seguinte Nota Oficiosa do Diretório do PRN: "A reunião ordinária de ontem do Diretório do PRN foi, principalmente ocupada na resolução de assuntos de natureza partidária. Foi, todavia, deliberado, no intuito de desfazer duma vez para sempre as cabalas ardidas manifestamente por inimigos do partido afirmar perentoriamente que não delegou, nem delegará em qualquer pessoa que do Diretório não faça parte, poderes para, em nome dele, falar, e menos ainda para negociar acordos que só o Diretório poderá fazer, visto que, por força do disposto na lei orgânica é o único representante do partido" (O Bejense 25/06/1925: 1). 
O Diretório procurou ter um conhecimento e controlo das atividades das comissões distritais, concelhias e paroquiais do $\mathrm{PRN}^{14}$. No entanto, estas estruturas tinham uma grande autonomia, tendo o Diretório muita dificuldade em controlar todas as estruturas e todos os notáveis locais, uma vez que o partido era mais um conglomerado do que um corpo articulado e disciplinado. Nunca foi possível ter um cadastro atualizado das diferentes comissões políticas e dos filiados.

Os membros do Diretório, enquanto principais líderes PRN, desempenhavam um papel fundamental como intermediários no acesso ao poder central e na resolução dos problemas dos correligionários com o Estado, sendo portanto um elo fundamental no sistema clientelar. José Troncho de Melo queria institucionalizar esta apelação aos membros do Diretório e, por isso, propôs a criação de uma secretária junto do Diretório que atendesse as reclamações dos correligionários da província, que os membros do Diretório deveriam tentar resolver junto das pessoas adequadas (Diário de Lisboa 17/03/1923: 3; República 18/03/1923: 2). A secretaria não foi criada, mas os membros do Diretório recebiam diretamente imensas cartas com todo tipo de pedidos dos correligionários de todo o país (Baiôa 2013: 326-338; 2014: 187-200).

A Representação Parlamentar do PRN era "uma entidade independente, com função política própria, mas harmónica com a ação geral política do Diretório" (Estatuto 1923: 11, Arto 35º). Estava dividida em duas secções autónomas, mas que podiam reunir em conjunto - Câmara dos Deputados e Senado. Cada uma das secções elegia por escrutínio secreto, no princípio de cada sessão parlamentar ordinária, por um ano, um líder, dois sublíderes e dois secretários. No ato fundacional do PRN, em 1923, procurou-se distribuir os lugares de maior visibilidade e influência pelas várias tendências partidárias. Álvaro de Castro (antigo líder reconstituinte) tornou-se o líder dos deputados, Cunha Leal e Ferreira de Mira (antigos

14 Circular enviada em julho de 1923 pela comissão organizadora do PRN para as comissões distritais e municipais, solicitando informações sobre a organização do partido (EAGM/BNP, Espólio E55/1705): "A República pode dizer-se, não teve, até agora, mais do que um partido a governar. De facto só o partido democrático tem sido detentor dos selos do Estado, só ele tem mandado, e das várias emergências e vicissitudes suportadas pelas instituições republicanas, outra coisa não resultou ainda, que não fosse a entrega do governo da nação aos democráticos, sem utilidade que tal justificasse". É necessário uma maior organização do PRN, "cujo Diretório precisa saber com quem e com que pode contar" [...]. "Solicitamos a fineza de nos informar do seguinte: Estão já organizados nesse concelho as comissões políticas do PRN? Em caso negativo, pode V. Ex. a, promover de acordo com as pessoas que saiba terem aceitado a orientação nacionalista, a organização das comissões políticas?” [...] Respostas para Dr. de Sousa da Câmara, Largo do Calhariz, 17, Lisboa". 
liberais) sublíderes e Sampaio Maia (antigo liberal) e Carlos de Vasconcelos (antigo reconstituinte) secretários (República 24/03/1923: 1). No ano seguinte, Cunha Leal foi eleito líder do grupo parlamentar, mantendo-se nesse cargo até 1926 (Diário de Lisboa 6/07/1925: 8). Afonso Henriques do Prado Castro e Lemos liderou o "Bloco" constituído pelo PRRN e pelo PRL no Senado em dezembro de 1922. Após a formação do PRN ainda dirigiu transitoriamente o grupo parlamentar no Senado (Diário do Senado 27/02/1923: 4). Posteriormente seria Augusto César de Almeida Vasconcelos Correia que chefiaria o PRN no Senado, entre fevereiro de 1923 a abril de 1926.

A Representação Parlamentar inicial do PRN rondava os 65 membros, fruto da fusão do grupo parlamentar do PRL e do PRRN (António Ginestal Machado, Diário de Lisboa 10/05/1923: 1 e 25/05/1923: 8). Ao longo da legislatura (1922-1925) o número de parlamentares do PRN desceu em virtude de alguns conflitos e dissidências, como a protagonizada por Álvaro de Castro. Na última legislatura (1925-1926) o PRN passou a contar com 44 membros no seu grupo parlamentar, embora também este ficasse reduzido a 31 membros após a cisão da União Liberal Republicana (ULR) em março de 1926 (Baiôa 2015: 62-353). A coesão do grupo parlamentar era fraca, sendo frequente alguns deputados e senadores contrariarem a posição do Diretório e do grupo parlamentar, o que potenciava conflitos, cisões e o abandono do partido por parte de alguns parlamentares. Ribeiro de Carvalho defendia que a coesão do grupo parlamentar do PRN e a sua relação com o Diretório deveria ter o seguinte enquadramento:

Como parlamentares só do «líder», seja ele qual for, temos que receber indicações. Os parlamentares entendem-se com o «líder». $\mathrm{O} \ll$ líder» entende-se com o Diretório, quando julga necessário. Isto é que é disciplina. Isto é que são normas a seguir, dentro de qualquer partido. Porque desde que um indivíduo ou um organismo invada as atribuições de outro, o resultado não pode deixar de ser este: confusão (Ribeiro de Carvalho, República 15/05/1923: 1).

Por vezes, também havia conflitos entre a Representação Parlamentar e o Diretório devido a decisões com sinal contrário em cada um destes órgãos. No dia 7 de julho de 1925 reuniu o grupo parlamentar do PRN, tendo deliberado proceder por modo a não derrubar o governo de António Maria da Silva. Esta deliberação era contrária à resolução tomada pelo Diretório e não foi consensual, dado que segundo alguns nacionalistas era uma atitude 
favorável ao PRP e prejudicial aos interesses do PRN, pelo que Pedro Pita e Raul Lelo Portela renunciaram aos seus lugares no Diretório ${ }^{15}$. Contudo, acabariam por permanecer nos seus lugares.

A Representação Parlamentar reunia ordinariamente uma vez por semana, embora pudesse reunir extraordinariamente com outra periodicidade para tratar qualquer assunto urgente. $O$ dia da semana em que ocorria a reunião foi variando, ainda que em outubro de 1923 acontecessem às quintas-feiras (República 18/10/1923: 2). A Representação Parlamentar era administrada por um regimento, que não foi possível identificar ${ }^{16}$. Os vogais do Diretório que não fossem parlamentares podiam participar, assistir e intervir nas reuniões do grupo parlamentar, mas não tinham direito a voto. A Representação Parlamentar devia estar organizada em tantas comissões quantos os ministérios existentes (Estatuto 1923: 12, $\operatorname{art}^{\circ} 36^{\circ}$ ). Estas comissões deveriam ser um grupo especializado para analisar e propor resoluções sobre diversas temáticas. No entanto, segundo Cunha Leal, a sua ação foi quase nula. Cunha Leal enquanto era líder parlamentar tentou formar comissões especializadas:

[Aconselhei a] nomeação de comissões, espécie de organismos técnicos do grupo, encarregados de estudar e resolver sobre esses problemas. [Contudo], o grupo só muito tarde nomeou as comissões que eu lhe havia sugerido. E, até agora, nenhuma dessas comissões deu parecer sobre qualquer das questões cujo estudo lhe foi cometido. Tive assim, nestas condições de falar em nome do partido sobre vários problemas (Leal, Acção Nacionalista 28/02/1926: 4).

Portanto, os parlamentares intervinham na Câmara dos Deputados e no Senado quase sempre com base na sua intuição e nos seus conheci-

15 Carta enviada por Pedro Pita ao presidente do Diretório do PRN, António Ginestal Machado (EAGM/BNP, Espólio E55/995): "PRN. Diretório / Lisboa, 7-7-1925 / Largo Calhariz, 17 / A resolução hoje tomada pelo Conselho Parlamentar de proceder por modo a não derrubar o governo, coloca-me na obrigação que cumpro - independentemente da circunstância de ser por esta revogada a deliberação anteriormente tomada pelo Diretório - de depor nas mãos de V. Ex. a a minha renúncia ao lugar de vogal - Diretório do nosso Partido!". Carta enviada por Raul Lelo Portela ao presidente do Diretório do PRN, António Ginestal Machado (EAGM/BNP, Espólio E55/1001): "Raul Lelo Portela / Rua de entre Campos, 11 / Lisboa / 8-7-1925 / [...] Soube que ontem o G. P. N. [Grupo Parlamentar Nacionalista] resolveu tomar uma atitude de... não embaraçar a vida do atual governo. Esta atitude é contrária à resolução tomada pelo Diretório. Esta atitude é um favor ao P. D. [Partido Democrático] e vem prejudicar os interesses do P.R.N. e mais os interesses da República. Por isso venho resignar ao meu lugar no Diretório e a depô-lo nas mãos de V. Ex.a”.

16 Foi nomeada uma comissão para elaborar o regimento do Grupo Parlamentar; cf. República 18/10/1923: 2 . 
mentos prévios e não com uma estratégia consertada e preparada antecipadamente.

A Representação Parlamentar reunia habitualmente no Parlamento. No entanto, também reuniu algumas vezes no Centro Nacionalista do Calhariz, sede do Diretório em Lisboa. Nalgumas ocasiões os parlamentares do PRN reuniram em função dos distritos onde tinham sido eleitos. Procuravam concertar as reivindicações para a sua região (República 27/02/1923: 1; 27/02/1923: 1). Por vezes, quando a situação o exigia, as reuniões realizavam-se em conjunto com o Diretório. Após o abandono do Parlamento pelos senadores e deputados nacionalistas em 2 de maio de 1923, o Diretório do PRN reunido na noite de 23 desse mês e ano decidiu convocar os parlamentares para uma reunião no dia seguinte pelas 21 horas (República 24/05/1923: 2) para equacionar continuar com a mesma atitude ou renunciar aos cargos. A reunião foi bastante concorrida e houve discussão agitada até às três da madrugada. O grupo parlamentar resolveu prolongar a sua ausência no Parlamento, retificando o seu voto de confiança no Diretório, tendo apenas sete dos 65 parlamentares nacionalistas votado contra a renúncia (República 25/05/1923: 2; Diário de Lisboa 25/05/1923: 8). Noutra ocasião, no dia 27 de junho de 1925, as duas estruturas reuniram para analisarem a atitude a tomar após a queda do governo liderado por Vitorino Guimarães. O Diretório e o grupo parlamentar do PRN decidiram transmitir ao Presidente da República a sua disponibilidade para assumir o poder sozinhos, ou então permaneceriam na oposição (Diário de Lisboa 27/05/1925: 5). Nas reuniões semanais ordinárias era feita a gestão política da intervenção dos deputados e senadores no Congresso, sendo tratados temas muito variados. Por vezes, no final destas reuniões era difundida uma nota à imprensa ${ }^{17}$. O processo de deliberações passava pela votação de moções e pela eleição dos seus líderes.

17 Veja-se a nota de imprensa divulgada após a reunião realizada no dia 24 de maio: "O Grupo Parlamentar nacionalista tomou conhecimento da intransigência do Partido Democrático em face da plataforma apresentada pelos independentes e aceite integralmente pelo Partido Nacionalista, e resolveu manter a sua atual atitude retificando o seu voto de confiança no Diretório" (República 25/05/1923: 2). 
Quadro 2. Comissão Administrativa do PRN (1923-1926)

\begin{tabular}{|l|c|c|c|c|}
\hline \multicolumn{1}{|c|}{ Nome } & \multicolumn{1}{c|}{$\begin{array}{c}1-0^{0} \\
\text { Congresso } \\
1923\end{array}$} & $\begin{array}{c}2.0^{\circ} \\
\text { Congresso } \\
1924\end{array}$ & $\begin{array}{c}3.0^{\circ} \\
\text { Congresso } \\
1925\end{array}$ & $\begin{array}{c}4.0^{\circ} \\
\text { Congresso } \\
1926\end{array}$ \\
\hline Inácio Pimentel & & & & \\
\hline João Rodrigues & & & & \\
\hline Júlio Maria de Sousa & & & & \\
\hline Manuel Martins Cardoso & & & & \\
\hline Raul de Carvalho & & & & \\
\hline Benjamim Fernandes Neves Tavares & & & & \\
\hline Elias Garcia & & & \\
\hline João Lúcio Escorcio & & & \\
\hline João Simões de Almeida & & & \\
\hline José Pais de Vasconcelos Abranches & & & & \\
\hline Jaime Pinto Serra & & & & \\
\hline Alfredo Soares & & & & \\
\hline Alípio Teixeira & & & & \\
\hline Agostinho Pires & & & & \\
\hline António Augusto da Costa Mota Sobrinho & & & & \\
\hline Eugênio Neves Lima & & & & \\
\hline Efetivo & & & & \\
\hline
\end{tabular}

O Congresso também elegia a Comissão Administrativa, órgão encarregue das finanças e da burocracia do partido, que era composto por cinco membros efetivos e cinco membros substitutos (Estatuto 1923: 5 e 10, arto $^{\circ} 15^{\circ}$ e 28 ${ }^{\circ}{ }^{18}$. Após o II Congresso do PRN, a Comissão Administrativa manteve-se quase inalterada, conforme se pode verificar no Quadro 2. Os elementos que compunham este órgão eram normalmente membros das estruturas intermédias do PRN. Não conseguimos obter muitas informações sobre a regularidade das suas reuniões (República, 11/04/1923), nem sobre as atividades administrativas realizadas por esta comissão, embora elas estivessem relacionadas com questões burocráticas, financeiras e contabilísticas do partido ${ }^{19}$. Não sabemos se havia algum cargo remunerado ou se havia funcionários do partido, embora as poucas informações disponíveis apontem para uma resposta negativa.

O PRN tinha ainda como órgão diretivo nacional a Junta Consultiva. A Junta Consultiva estava incumbida de dar pareceres e de pedir esclare-

18 No PRL a Comissão Administrativa tinha a mesma composição, cf. Estatuto 1919: 9, cap. V, arto $24^{\circ}$.

19 Numa reunião da Comissão Administrativa ficou "assente a impressão e distribuição dum questionário estatística aprovado pelo Diretório do Partido” (O Jornal 17/05/1924: 1). 
cimentos ao Diretório e era composta por um número alargado de atuais e antigos membros da elite do PRN e dos seus partidos predecessores ${ }^{20}$, nomeadamente:

a) Pelos vogais substitutos do Diretório que não estejam em exercício; b) Pelos vogais efetivos e substitutos da comissão administrativa; c) Pelos ex-vogais efetivos do Diretório; d) Pelos Ministros e ex-ministros; e) Pelos deputados e senadores, e pelos antigos deputados e senadores; f) Pelos governadores e ex-governadores de província ou distritos ultramarinos; g) pelos governadores civis e ex-governadores civis; h) Pelos presidentes das comissões distrital e municipal de Lisboa e por quatro delegados eleitos pelas comissões paroquiais de cada um dos quatro bairros da mesma cidade (Estatuto 1923: 10-11, arto $\left.31^{\circ}\right)$.

Portanto, a maioria dos membros deste órgão eram delegados de direitos (ocupação de um cargo) e uma minoria eram delegados eleitos. Era um órgão que reunia a elite alargada do PRN, com os seus históricos notáveis, alguns ligados aos partidos antecessores do PRN, mas já sem atividade política ativa nesse momento.

A Junta Consultiva reunia quando convocada pelo Diretório ou por iniciativa própria. Registamos dez reuniões deste órgão político ${ }^{21}$, sendo a primeira reunião a 7 de maio de 1923 e a última em 9 de outubro de 1930. Os temas tratados nestas reuniões eram normalmente de grande transcendência para vida interna do partido ou relacionados com a situação política nacional. Na reunião de 7 de maio de 1923 foi analisado o abandono do Congresso por parte dos parlamentares nacionalistas ${ }^{22}$, na reunião de 8 de novembro desse ano foi estudada a possibilidade de constituir um governo extrapartidário presidido por Afonso $\operatorname{Costa}^{23}$ e na reunião de 15 de dezembro de 1923 a Junta Consultiva pronunciou-se sobre a possibilidade de participar em governos de concentração. Nas reuniões de 27 de agosto e de 3 de setembro de 1925 tomaram-se essencialmente decisões sobre as candidaturas a apresentar nas

20 No PRP a Junta Consultiva era constituída por quinze membros eleitos bienalmente em Congresso e por dez deputados e cinco senadores eleitos pelo Grupo Parlamentar. Cf. Lei Orgânica 1921: 10, cap. VIII, $\operatorname{art}^{\circ} 28^{\circ}$.

21 Datas das reuniões da Junta Consultiva do PRN: 07/05/1923; 08/11/1923; 15/12/1923; 27/08/1925; 03/09/1925; 03/11/1926; 28/10/1927; 04/11/1927; 06/09/1930; 09/10/1930.

22 República 3/05/1923: 1, 5/05/1923: 1 e 9/05/1923: 2; Diário de Lisboa 10/05/1923: 1; EAGM/ BNP, Espólio E55/741, Carta enviada Álvaro Xavier de Castro, 9/05/1923, Lisboa.

23 Diário de Lisboa 8/11/1923: 8 e 12/11/1923: 8; República, 9/11/1923: 1 e 8/11/1923: 1; O Combate 25/11/1923: 2 . 
eleições legislativas desse ano ${ }^{24}$. Após o início da Ditadura Militar, a Junta Consultiva ganhou uma relevância maior, dada a impossibilidade de convocar o Congresso do PRN. Na reunião de 3 de novembro de 1926 apoiou-se a posição assumida pelo Diretório face à Ditadura Militar (Notícias de Viseu 6/11/1926: 1; O Debate 7/11/1926: 1). Nas reuniões de 28 de outubro e 4 de novembro de 1927 foi analisado e retificado o projeto constitucional apresentado por António Ginestal Machado (Diário de Lisboa 29/10/1927: 8; Diário de Lisboa 5/11/1927: 8). Por fim, nas reuniões de 6 de setembro e 9 de outubro de 1930 foi analisado o problema do lançamento da União Nacional e a atitude que o partido deveria tomar face à situação política vigente ${ }^{25}$. A partir desta data não foi possível reunir este órgão devido às limitações impostas pelo Governo da Ditadura Militar. Nestas reuniões participavam geralmente 50 a 80 membros e as deliberações eram normalmente tomadas após discussão e votação de moções.

\section{Os órgãos diretivos locais}

A nível regional, o PRN estava organizado em moldes tradicionais, seguindo a estrutura administrativa (comissões distritais, municipais e paroquiais). Álvaro de Castro ainda tentou que a organização estivesse centrada nos círculos eleitorais, conforme estava organizado no Partido Republicano de Reconstituição Nacional (Silva, 1996: 66-68), de forma a tentar obter maior êxito eleitoral ${ }^{26}$. No entanto, acabou-se por manter a estrutura clássica dos partidos portugueses que tinha sido seguida pelo PRL (Estatuto 1919: 11, cap. VIII, art $\left.{ }^{\circ} 33^{\circ}\right)$. O PRP, o PRED e a ULR optaram neste período por constituir "Comissões de Círculo Eleitoral" ou "Federações Municipais" nas sedes dos círculos eleitorais ${ }^{27}$.

As comissões distritais eram constituídas por cinco vogais efetivos e cinco vogais substitutos eleitos por dois delegados de cada comissão municipal. As comissões municipais tinham uma dimensão flexível em função da grandeza do concelho e da força do PRN. As comissões municipais de Lisboa e do Porto eram constituídas respetivamente, por doze e nove membros efe-

\footnotetext{
24 O Imparcial 28/08/1925: 4; Gazeta de Viana 10/09/1925: 1; Acção Nacionalista 13/09/1925: 4.

25 Diário de Lisboa 30/08/1930: 12 e 9/10/1930; Correio da Extremadura, 13/09/1930: 1.

26 Álvaro de Castro defendia que a organização do PRN deveria ser "diversa do que tem sido. A base das comissões e núcleos não está nos distritos, nem nos concelhos. Mas sim nos círculos” (Álvaro de Castro, Diário de Lisboa 27/01/1923: 8).

27 Lei Orgânica 1921: 8-9, cap. VI, artº 21ํ-25º; A Noite 21/04/1926: 3; Queirós 2008: 204-205.
} 
tivos e igual número de substitutos. Os restantes concelhos podiam constituir comissões de sete, cinco ou três membros efetivos. Nos concelhos onde não fosse possível constituir uma comissão o Diretório nomearia um cidadão que representaria os interesses do PRN no concelho (Estatuto 1923: 12, art $^{\circ}$ $37^{\circ}-38^{\circ}$ ). As comissões paroquiais (ou de freguesia) eram constituídas por três vogais efetivos e igual número de vogais substitutos, com exceção das comissões de freguesia de Lisboa e Porto que eram compostas por sete e cinco membros, respetivamente (Estatuto 1923: 12, arto 39o). Cada uma das comissões elegia um presidente e um secretário. As comissões distritais, concelhias e paroquiais estavam subordinadas aos órgãos hierarquicamente superiores, nomeadamente o Diretório. As principais funções destas comissões eram a organização partidária e a expansão do partido na sua área de influência. As comissões paroquiais (ou de freguesia) não serão objeto de análise aprofundada neste estudo.

Ao nível das comissões distritais identificamos quinze órgãos políticos com atividade: Comissão Distrital de Beja, Braga, Castelo Branco, Coimbra, Évora, Guarda, Lisboa, Portalegre, Porto, Santarém, Viana do Castelo, Vila Real, Viseu, Funchal e de Ponta Delgada ${ }^{28}$. Não foram identificadas comissões distritais do PRN em Aveiro, Bragança, Faro, Leiria, Angra do Heroísmo e Horta. No entanto, é possível que tenham existido, pois as atividades das comissões distritais eram reduzidas e tinham pouca repercussão na imprensa. A ação política no terreno estava principalmente nas mãos das comissões municipais, cabendo às comissões distritais um papel ativo na negociação com o Diretório dos candidatos a deputado e senador pelos seus distritos. Esta escolha provocou, por vezes, algumas tensões com o Diretório e com as comissões municipais (Baiôa 2015: 252-326). Nos casos em que não havia acordo, cabia ao Diretório o parecer definitivo (Estatuto 1923: 9 e 13, art $^{\circ}$ $27^{\circ} \mathrm{e} 41^{\circ}$ ). A escolha dos candidatos às eleições administrativas era normalmente mais pacífica.

Identificamos 161 Comissões Municipais do PRN no continente, o que representava $60,1 \%$ do total dos concelhos de Portugal continental. Se tomarmos em consideração o continente e as ilhas adjacentes, o PRN estava organizado em 171 concelhos, o que representava $57,6 \%$ do total dos concelhos

28 EAGM/BNP, Espólio E55/1063; A Norma 25/01/1923: 2; Acção Nacionalista 6/07/1925: 4 e 6/09/1925: 2; Correio da Estremadura 12/05/1923: 2; Diário do Minho 23/03/1926: 1; Distrito da Guarda 18/02/1923: 1; O Bejense 29/10/1925: 1; O Debate 20/04/1924: 1; O Figueirense, 19/04/1923: 1; O Jornal 24/12/1923: 4, 27/12/1923: 2, 29/12/1923: 1, 1/07/1924: 1; O Século 13/01/1923: 2; República, 13/03/1923: 1, 14/04/1923: 2, 19/04/1923: 2, 22/11/1923: 1 e 1/12/1923: 1 . 
de Portugal continental e insular. Os distritos com uma malha mais densa de comissões municipais do PRN eram os de Coimbra, Braga, Funchal, Vila Real, Faro, Santarém, Lisboa e Porto. Pelo contrário, os distritos de Aveiro e da Guarda eram onde a rede de comissões municipais era mais escassa no continente (Quadro 3). Nas ilhas adjacentes ressalta a fraca rede de comissões municipais nos Açores, com apenas uma comissão municipal identificada. No entanto, é provável que tenham existido mais algumas comissões, que poderão surgir noutros estudos mais focados em algumas regiões. Nas colónias não foi identificada nenhuma estrutura organizativa do PRN.

Estes dados revelam uma presença forte e relativamente homogénea do PRN nas várias regiões da metrópole, mas também demonstram que era o segundo partido do país ao nível da organização partidária. Segundo Oliveira Marques, o PRP possuía 19 comissões distritais e 256 comissões municipais na metrópole em 1914 (Marques 1991: 409). Não existem dados seguros para o período de 1923 a 1926, mas o PRP continuava, por certo, com uma rede partidária mais consistente do que o PRN. No entanto, o PRN estava bastante à frente do Partido Republicano da Esquerda Democrática, uma vez que este apenas estava organizado em duas federações municipais (situadas nas sedes dos círculos eleitorais) e em 46 comissões municipais (Queirós 2008: 204-208). O PRN também tinha uma rede política mais densa do que os seus partidos predecessores, como o Partido Republicano Evolucionista, que apenas conseguiu ter comissões políticas em seis distritos e em 89 concelhos em 1915 (Marques 1991: 412) ou o Partido Republicano de Reconstituição Nacional que dispunha apenas de 90 comissões (entre distritais e municipais) entre 1920 e 1923 (Silva 1996: 61-62).

Quadro 3. Comissões Municipais do PRN por Distrito

\begin{tabular}{|l|c|c|c|}
\hline \multicolumn{1}{|c|}{ Distrito } & $\begin{array}{c}\text { No de Concelhos } \\
\text { no Distrito }\end{array}$ & $\begin{array}{c}\text { Comissões Municipais } \\
\text { do PRN }\end{array}$ & $\begin{array}{c}\text { \% de comissões } \\
\text { face ao total }\end{array}$ \\
\hline Coimbra & 17 & 16 & $94,1 \%$ \\
\hline Braga & 13 & 12 & $92,3 \%$ \\
\hline Vila Real & 14 & 11 & $78,6 \%$ \\
\hline Faro & 16 & 12 & $75,0 \%$ \\
\hline Santarém & 20 & 15 & $75,0 \%$ \\
\hline Lisboa & 14 & 10 & $71,4 \%$ \\
\hline Porto & 17 & 12 & $70,6 \%$ \\
\hline Castelo Branco & 11 & 7 & $63,6 \%$ \\
\hline Viana do Castelo & 10 & 6 & $60,0 \%$ \\
\hline Beja & 14 & 8 & $57,1 \%$ \\
\hline Portalegre & 15 & 8 & $53,3 \%$ \\
\hline Leiria & 15 & 7 & $46,7 \%$ \\
\hline
\end{tabular}




\begin{tabular}{|l|r|r|c|}
\hline Évora & 13 & 6 & $46,2 \%$ \\
\hline Bragança & 12 & 5 & $41,7 \%$ \\
\hline Setúbal ${ }^{29}$ & 12 & 5 & $41,7 \%$ \\
\hline Viseu & 24 & 10 & $41,7 \%$ \\
\hline Guarda & 14 & 5 & $35,7 \%$ \\
\hline Aveiro & 17 & 6 & $35,3 \%$ \\
\hline Total Continente & 268 & 161 & $60,1 \%$ \\
\hline $\begin{array}{l}\text { Angra do Heró́smo; Horta; Ponta } \\
\text { Delgada }\end{array}$ & 18 & 1 & $5,5 \%$ \\
\hline Funchal & 11 & 9 & $81,8 \%$ \\
\hline Total Continente e ilhas adjacentes & $\mathbf{2 9 7}$ & $\mathbf{1 7 1}$ & $\mathbf{5 7 , 6 \%}$ \\
\hline
\end{tabular}

Fonte: Baiôa 2012: Anexo 2.

Algumas das comissões distritais e municipais do PRN tiveram vida efémera. Esta falta de consistência das comissões locais poderia ser ultrapassada, segundo alguns nacionalistas, pela dinâmica dos órgãos centrais do PRN. José O’Neill Pedrosa, presidente do Centro Republicano Nacionalista Dr. Jacinto Nunes, defendia o seguinte:

[Era] absolutamente necessário admitir-se e dar seguimento à proposta tantas vezes alvitrada nos Congressos, na qual se pediu que cada círculo eleitoral tivesse uma comissão política central nomeada pelo Diretório composta de cinquenta vogais que tenham provado prestígio no círculo. [Pois], em muitos círculos, e não muito longe de nós, nem comissões políticas do nosso partido existem nos diversos concelhos (José O’Neill Pedrosa, Acção Nacionalista 15/02/1925: 1).

Houve uma redução do número de comissões políticas do PRN com as cisões lideradas por Álvaro de Castro em dezembro de 1923 e por Cunha Leal em março de 1926, que foi impossível contabilizar com rigor. Contudo, foi após o início da Ditadura Militar que se acelerou o desaparecimento de grande parte das estruturas regionais do PRN, fruto da hostilidade das novas autoridades para com os partidos políticos e devido à desmobilização dos próprios membros do PRN. Numa sociedade marcada pelo clientelismo, os notáveis do PRN, à semelhança dos outros partidos republicanos, perderam capacidade de medição com a afirmação do regime autoritário, pelo que muitos "clientes" mudaram rapidamente de "patrono" (Baiôa 2015: 364-464).

As comissões municipais e distritais reuniam geralmente nos centros políticos nacionalistas. Nos locais onde não existiam centros, as reuniões rea-

29 O Distrito de Setúbal autonomizou-se do Distrito de Lisboa em 22 de dezembro de 1926. 
lizavam-se frequentemente nas casas dos notáveis locais ${ }^{30}$. Algumas comissões municipais tinham reuniões semanais, como a Comissão Municipal do PRN do Porto, que reunia aos sábados (O Jornal 5/01/1924: 1). Contudo, a maioria das comissões municipais apenas reunia nos períodos eleitorais, tendo uma atividade pouco consistente e duradoira. A eleição destas comissões era um puro ato administrativo, uma vez que nunca havia concorrentes, sendo as listas "cozinhadas" pelos notáveis locais.

Esta falta de transparência, pluralismo e democracia nas eleições internas também era evidente nas reuniões partidárias locais. Durante estas reuniões havia o que se pode chamar "decisão por interpretação". As reuniões eram mais para dar conhecimento do que para debater. As propostas eram normalmente aprovadas por ovação e não por votação (Silva, 1996: 66-67). Veja-se como exemplo a reunião realizada em fevereiro de 1923 em Évora, entre liberais e reconstituintes, para decidir da fusão dos dois partidos. Foram dadas várias informações, mas não houve nenhum debate. A reunião terminou enviando-se um telegrama a saudar o novo partido (Democracia do Sul 29/02/1923: 2). O mesmo sucedeu na reunião para analisar a decisão do Diretório do PRN de não viabilizar um governo presidido pelo Dr. Afonso Costa (Democracia do Sul 14/11/1923: 2), ou na indicação de um correligionário para o cargo de Governador Civil de Évora (Democracia do Sul 20/11/1923: 2). As comissões serviam quase só para idolatrar e aclamar os líderes - "para dar vivas". Imperava uma cultura de dependência e de submissão aos líderes, estando os elementos de base numa posição passiva (Silva 1996: 72). As moções e decisões eram tomadas habitualmente por aclamação para criar uma impressão de unanimidade e unidade do partido ${ }^{31}$. No entanto, revelavam, acima de tudo que era uma pequena elite que dominava o partido, tomava as decisões importantes e distribuía os recursos disponíveis (Baiôa 2013: 326-338 e 2014: 187-200). A título de exemplo, veja-se a seguinte carta enviada por Jaime Dias, funcionário no Governo Civil de Castelo Branco, para o deputado do PRN, Bernardo Ferreira de Matos, que era o seu patrono em Lisboa:

Gabinete do Governador Civil do Distrito de Castelo Branco / Meu caro Dr. / Venho informá-lo. / Meu irmão António Lopes Dias concorreu a toda a série

\footnotetext{
30 No dia 13 de junho de 1923 reuniram-se os membros do PRN do concelho de Alenquer no consultório do Dr. Duarte Rosa Ramos a fim de serem eleitas a comissão concelhia e as comissões de freguesia do concelho de Alenquer; cf. A Razão 20/06/1923: 1.

31 Cf. a moção aprovada por aclamação no Centro Político Nacionalista de Portalegre, República 4/01/1924: 1.
} 
de escolas que constam da Lista da Junta. Tenho o maior empenho em que ele seja colocado em qualquer delas e como não me é possível ir agora a Lisboa muito lhe agradeço de tomar o caso à sua conta e proteção. Não faz questão de localidade, a questão é ser nomeado e como ele tem classificação regular, creio que poderá conseguir-se. / Estão já nomeados os administradores da Sertã e Proença-a-Nova. Sobre o Governador Civil, como as comissões reúnem hoje, só amanhã poderei dizer-lhe alguma coisa na certeza porém de que $[. .$.$] todos$ servem desde que representem a opinião e sentir do partido, que deve manter-se mais do que nunca firme e unido. [...] Sobre os administradores: Já devem ter tomado posse os que me indicou. /19-11-1923 / Jaime Dias (Espólio Bernardo Ferreira de Matos - Lisboa - em posse da família).

Os líderes nacionais do PRN raramente sentiam necessidade de ouvir as bases do partido. Alberto Xavier, entrevistado por um jornalista do Diário de Lisboa sobre a hipótese de serem consultados os eleitores do PRN em todos os círculos para os ouvirem sobre a possibilidade dos parlamentares do PRN regressarem ao Parlamento, disse o seguinte:

- Não. Não vale a pena. Por exemplo, eu não consulto o meu.

- Porquê?

- Porque já sei que a resposta não pode deixar de ser afirmativa (Alberto Xavier, Diário de Lisboa 28/05/1923: 5).

Contudo, em Lisboa, o contexto era um pouco diferente. A comissão distrital e municipal de Lisboa procurou organizar um cadastro das comissões políticas e dos seus associados ${ }^{32}$ e estreitar os laços entre as várias estruturas do partido ${ }^{33}$. No entanto, no resto do país a maioria das estruturas funcionavam desligadas umas das outras, com pouca articulação vertical e horizontal.

Esta realidade não era muito diferente do que se passava em alguns partidos da Europa da mesma época. No Partido Radical Francês as comissões políticas urbanas eram bastante mais ativas do que as rurais. Reuniam habitualmente uma vez por mês, com um interregno nos meses de verão, e tinham

32 Comissão Distrital de Lisboa: "Foi deliberado organizar com toda a brevidade o cadastro partidário do distrito e nessa ordem de ideias vai ser enviada circular a todas as comissões municipais para fornecerem os elementos necessários para tal fim" (O Jornal 5/06/1924: 1).

33 Em abril de 1924, os secretários da Comissão Municipal de Lisboa apresentaram os documentos para elaborar o cadastro do PRN em Lisboa, constituído por dois boletins que ficam arquivados em duplicado: um na comissão política de freguesia e outro na comissão municipal. Nesse momento encontravam-se organizadas 42 comissões do PRN em Lisboa. Resolveu-se que um ou dois membros da Comissão Municipal participassem nas comissões de freguesia para estreitar laços para uma maior coesão partidária (cf. O Jornal 4/04/1924: 1). 
uma maior atividade antes dos atos eleitorais. Estas reuniões mostravam que muitos membros eram passivos e que os cargos dirigentes pertenciam quase sempre aos mesmos cidadãos. As temáticas das reuniões centravam-se em questões internas, como os novos aderentes ao partido, problemas eleitorais locais e questões de política geral. As discussões sobre as decisões dos órgãos centrais do partido não eram relevantes, dado que os aderentes confiavam nos chefes nacionais (Berstein 1980: 180-181). No entanto, os partidos de massas emergentes começaram a operar uma transformação na organização interna, ganhando os elementos de base um protagonismo maior. Por exemplo, no Partido Socialista Italiano o referendo interno passou a ser a base das decisões mais importantes (Ridolfi 1992: 41).

\section{Conclusão}

O Partido Republicano Nacionalista tinha um estatuto e uma estrutura organizativa semelhante aos restantes partidos republicanos. O Diretório era o órgão diretivo supremo do PRN. Era eleito anualmente pelo Congresso, órgão onde residia a soberania partidária. $O$ Congresso também elegia a Comissão Administrativa, órgão encarregue das finanças e da burocracia do partido. O PRN tinha ainda como órgãos diretivos nacionais, a Junta Consultiva e a Representação Parlamentar dividida em duas secções autónomas, mas que podiam reunir em conjunto - Câmara dos Deputados e Senado. A Junta Consultiva estava incumbida de dar pareceres ao Diretório e era composta por um número alargado de atuais e antigos membros da elite do PRN e dos seus partidos predecessores. A nível regional, o PRN estava organizado em função da estrutura administrativa (comissões distritais, municipais e de freguesia/paroquia).

A tomada de decisões no partido estava centralizada no Directório e no Grupo Parlamentar e a nível local nos notáveis, ainda que em termos formais fossem as comissões distritais e concelhias que tivessem essa legitimidade. As estruturas distritais e concelhias lideradas pelos caciques tinham uma grande autonomia funcional, permitindo-lhe realizar alianças nas quais os interesses familiares e as incompatibilidades pessoais estavam acima das teorias ideológicas.

O PRN tinha uma densa rede partidária nalguns distritos, como Coimbra, Braga, Vila Real, Faro, Santarém, Lisboa e Porto. Porém, ainda estava bastante atrás do PRP em número de comissões políticas. A rede de estruturas regionais do PRN atingiu o seu apogeu no final de 1923. Nos anos 
seguintes as comissões políticas do $\mathrm{PRN}$ foram diminuindo, principalmente após as cisões ocorridas em dezembro de 1923 e em março de 1926, e após o início da Ditadura Militar.

O PRN tinha um aparato organizativo bastante simples, típico dos partidos de quadros, ainda sem um rol de funcionários que caracterizavam os partidos de massas em ascensão na Europa. A organização assentava num conjunto alargado de notáveis e caciques, unidos entre si por laços de parentesco e clientelas. Apenas havia comissões estáveis e com trabalho regular nalgumas cidades. As reuniões partidárias faziam-se nos centros ou nas casas dos notáveis.

Em suma, embora começassem a surgir alguns elementos de modernização, o PRN continuava com uma organização deficiente, irregular, intermitente e pouco estruturada. Ainda que teoricamente tivesse um modelo organizativo centralizado, na prática, os organismos e os notáveis locais tinham uma autonomia vasta e indeterminada, sendo por isso bastante indisciplinados. Apesar do Diretório e do Grupo Parlamentar serem as principais cúpulas dirigentes do partido, existia uma grande autonomia dos caciques locais. Na maior parte do país o PRN estava organizado numa confederação pouco coesa e flexível de comissões locais independentes, chefiadas por um notável, com uma fraca conexão horizontal e vertical com as outras estruturas partidárias. As relações dentro do partido eram acima de tudo pessoais e não institucionais. $\mathrm{O}$ dinamismo do partido assentava mais no somatório da força dos seus notáveis, do que no partido enquanto organização. A maioria dos aderentes ao PRN continuava a estar vinculada a um notável e não diretamente ao partido.

\section{Bibliografia}

\section{Fontes arquivísticas}

Espólio António Ginestal Machado - Biblioteca Nacional de Portugal (EAGM/BNP), Espólio E55.

Espólio Bernardo Ferreira de Matos - Lisboa (em posse da família).

\section{Fontes hemerográficas}

Acção Nacionalista, Lisboa 1924-1926.

O Bejense, Beja 1923-1930.

O Combate, Guarda 1923-1925.

Correio da Estremadura, Santarém 1923-1931. 
O Debate, Oeiras 1923-1932.

Democracia do Sul, Évora 1923-1932.

Diário de Lisboa, Lisboa 1923-1935.

Diário do Minho, Braga 1925-1926.

Diário do Senado, Lisboa 1923-1926.

Distrito da Guarda, Guarda 1923-1926.

O Figueirense, Figueira da Foz 1923-1926.

Gazeta de Viana, Viana do Castelo 1923-1925.

O Imparcial, Lisboa 1925.

O Jornal, Lisboa 1923-1924.

A Noite, Lisboa 1926.

A Norma, Póvoa do Varzim 1922-1926.

Notícias de Viseu, Viseu 1923-1929.

A Razão, Alenquer 1923-1925.

O Regionalista, Caldas da Rainha 1923-1925.

República, Lisboa 1923-1935.

O Século, Lisboa 1923-1935.

\section{Fontes impressas}

Estatutos da União Liberal Republicana. Anexo C de LEITE, Ricardo Pinto (1995). “União Liberal Republicana (ULR) 1926-1930 (um partido político na transição de I República para o Salazarismo)”, Polis. Revista de Estudos Jurídico-Políticos, 4-5, 199-207.

PARTIDO REPUBLICANO LIBERAL (1919). Estatuto ou Lei Orgânica. Lisboa: Tipografia Bayard.

PARTIDO REPUBLICANO NACIONALISTA (1923). Estatuto ou Lei Orgânica do Partido Republicano Nacionalista. Lisboa: Tipografia e Papelaria Pires \& $\mathrm{Ct}^{\mathrm{a}}$.

PARTIDO REPUBLICANO PORTUGUÊS (1921). Lei Orgânica. Lisboa: Tip. da Sociedade Editorial Democrática.

\section{Estudos}

BAIÔA, Manuel (2012). Elites e organizações políticas na I República Portuguesa: o caso do Partido Republicano Nacionalista (1923-1935). Évora: Universidade de Évora (tese de doutoramento policopiada).

BAIÔA, Manuel (2013). “O Partido Republicano Nacionalista e o Clientelismo (19231935)”, in Maria Fernanda Rollo et al. (coord.), Atas I Congresso de História Contemporânea. [s.1.]: IHC / CEIS20 / Rede História, 326-338. 
BAIÔA, Manuel (2014). “A elite do Partido Republicano Nacionalista (1923-1935): perfil social e sociabilidade”, História. Revista da FLUP, 4a série, 4, 187-200.

BAIÔA, Manuel (2015). O Partido Republicano Nacionalista 1923-1935. “Uma República para Todos os Portugueses”. Lisboa: Imprensa de Ciências Sociais.

BAIÔA, Manuel (no prelo). "Os centros políticos, a imprensa e o financiamento do Partido Republicano Nacionalista (1923-1935)”, in II Congresso I República e Republicanismo. Lisboa: Centro República, 127-145.

BERSTEIN, Serge (1980). Histoire du Parti Radical. La recherche de l'âge d'or (1919-1926). Paris: Presses de la Fondation National des Sciences Politiques.

MARQUES, A. H. de Oliveira (coord.) (1991). Portugal da Monarquia para a República. Lisboa: Editorial Presença.

QUEIRÓS, António José (2008). A Esquerda Democrática e o final da Primeira República. Lisboa: Livros Horizonte.

RIDOLFI, Maurizio (1992). Il PSI e la nascita del partito di massa, 1892-1922. Roma: Laterza.

SILVA, João Manuel Garcia Salazar Gonçalves da (1996). O Partido Reconstituinte: clientelismo, faccionalismo e a descredibilização dos partidos políticos durante a Primeira República (1920-1923). Lisboa: ICS (dissertação de mestrado policopiada). 